\title{
Relationship between Portfolio Distribution, Management, and Composition and the Performance of Brazilian Fixed-Income Investment Funds (2011-2018)
}

\author{
Bruno Boalin', Rafael Confetti Gatsios ${ }^{2}$, Fabiano Guasti Lima², Rafael Moreira Antônio² \\ ${ }^{1}$ Department of Economics, University of São Paulo, Ribeirão Preto, Brasil \\ ${ }^{2}$ Department of Accounting, University of São Paulo, Ribeirão Preto, Brasil \\ Email: brunoboalim@hotmail.com,rafaelgatsios@hotmail.com, fgl@usp.br, Rafael.antonio@usp.br
}

How to cite this paper: Boalin, B., Gatsios, R. C., Lima, F. G., \& Antônio, R. M. (2020). Relationship between Portfolio Distribution, Management, and Composition and the Performance of Brazilian Fixed-Income Investment Funds (2011-2018). Theoretical Economics Letters, 10, 305-321. https://doi.org/10.4236/tel.2020.102021

Received: February 12, 2020

Accepted: April 20, 2020

Published: April 23, 2020

Copyright $\odot 2020$ by author(s) and Scientific Research Publishing Inc. This work is licensed under the Creative Commons Attribution International License (CC BY 4.0).

http://creativecommons.org/licenses/by/4.0/

\begin{abstract}
This study analyzes the relationship between portfolio distribution, management, and composition indicators and the performance of fixed-income funds in Brazil. It provides support to investors when making decisions regarding their investments. A sample composed of 1039 Brazilian fixed-income funds from January 2011 to December 2019 was analyzed using a panel data analysis methodology and considering robust standard errors. The performance fee charged by funds was found to be the variable that most helped increase the performance of Brazilian fixed-income funds. In addition, portfolios characterized by a higher proportion of fixed-income assets, less experienced management, managers concurrently responsible for a large number of funds, and greater net assets contributed substantially to improved fund performance, by generating the best risk-adjusted returns.
\end{abstract}

\section{Keywords}

Fixed-Income Investment Funds, Sharpe Index, Performance

\section{Introduction}

The growth of investment funds in Brazil is linked with the growth of the country's overall financial market. According to a survey by ANBIMA (Associação Brasileira das Entidades dos Mercados Financeiros e de Capitais, 2018), the total net equity allocated to investment funds reached the historical mark of $\mathrm{R} \$ 4.78$ trillion in 2018.

The interest from both managers and investors follows similar paths. While 
the performance of funds is an attractive earnings opportunity, managers also use this performance to signal their financial dominance and operation style. Meanwhile, when investors feel comfortable trusting their assets to qualified and experienced professionals in the market, they allocate their investments accordingly (Maestri \& Malaquias, 2017).

In this context, several studies evaluating the determinants of fund performance have been conducted. Studies indicate that factors such as political events, economic conditions, and the market expectations themselves interact deeply in the financial market to achieve possible positive returns due to the active participation of managers, who demonstrate their skills based on their firms' performance (Maestri \& Malaquias, 2017).

This study seeks to fill the gap observed in the literature with respect to the analysis of the performance determinants of fixed-income funds in the current Brazilian economic situation. With the objective of assessing the aforementioned issues, the following research question was formulated: What factors determine the performance of fixed-income funds in Brazil?

To answer the research question, several factors relating to managerial performance in the preparation of the portfolio composition, amount of funds managed, fees charged, and experience in the market, which affect national fixedincome funds, were evaluated. This study thus provides more informational content for investors when deciding how to allocate their resources. The research sample is composed of monthly data released by Economática and the Securities and Exchange Commission (CVM) from January 2011 to December 2018. The study used a panel data analysis methodology for the evaluation of the proposed relationships.

The results indicate that the performance fee charged by the funds was the variable that most helped to increase the performance of Brazilian fixed-income funds. Portfolios consisting of a higher percentage of fixed-income assets, less experienced management, managers with a higher number of concurrent funds, and greater net equity contributed substantially to improving fund performance, by generating the best risk-adjusted returns.

\section{Theoretical Framework}

A significant portion of the financial resources in Brazil are comprised of investment funds. According to data provided by ANBIMA, the volume invested by individuals in 2018 exceeded $\mathrm{R} \$ 3$ trillion. According to the institutional portal (Investor Portal) of the CVM, investment funds are a collection of resources from investors, categorized as a form of condominium, modeled as a collective investment structure with the objective of distributing the equity in financial assets. Their management follows strict rules imposed by the CVM, and it has its own regulations; its investment policy, objective, expenses, risks, traded assets, and other relevant information is formally documented. This product has different types of segmentation, each with its own allocation characteristic. 
Based on the provided definition and through CVM Instruction 555 (December 17, 2014), the main risk factor for funds classified as "Fixed-income" is their portfolio risk, including changes in interest rates, price indices, or both, and they are obliged to allocate a minimum of $80 \%$ of their equity to this kind of asset (e.g., federal government bonds, debentures, or time deposits). However, other securities and strategies can be allocated with a higher degree of risk, such as private credit and derivatives, aiming at improving performance.

When analyzing the performance of the funds, Fonseca et al. (2018) evaluated the behavior of Brazilian investment funds, comparing the performance of real returns with parameters relating to size, market, time, resources, cost, and risk.

One of the first studies with worldwide relevance was the Capital Asset Price Model and was based on fundamental assumptions in asset pricing through mean and variance analysis. To improve this model, four-factor models were presented. These added two risk measures, which represented value, size (bookto-market), and the momentum effect (Jegadeesh and Titman apud Fonseca et al., 2018). Despite the fact that there was no persistence in returns from Brazilian funds between 2001 and 2014, the momentum effect was relevant, which was important for clarifying abnormal fund performance, and was then complemented by the indicators (Nerasti and Lucinda apud Fonseca et al., 2018).

Additionally, using the Malmquist Index, they analyzed the way in which fund efficiency reacted based on risks and returns. They noticed a considerable drop in portfolio returns for 2008 and 2009, which were periods with high volatility. In this sense, the models proved that greater uncertainty regarding the momentum effect leads to greater volatility, supporting the question of applicability and particularity of measuring the performance of the fund assets (Fonseca et al., 2018).

Bessa and Funchal (2012) investigated the relationships between the institutional factors of funds, for example, the family flow and size. Given the direct relationship that exists between the fund flow and its returns, the presence of positive flow in the present could lead to positive returns in the future, which encourages investors to allocate their equity to these funds. There could be two analyses for the family factor. In the first, the return is positive when analyzing the family of funds, thereby generating an economy of scope in which the families of funds would save in fees and operating costs (Lynch and Musto apud Bessa and Funchal, 2012). In the second, Iquiapaza (2009) found no evidence indicating that the degree of specialization of the families would generate a greater return to the fund shareholders. The relationship between fund size and return generation seems to be negative due to high fees and operating costs, which would also go against the scale gains (Grimblatt and Titman apud Bessa and Funchal, 2012).

Interestingly, they showed the negative relationship between fund age and performance; newer funds tend to yield higher returns than older ones, precisely 
because they still expect favorable results in the future (Sawick and Finn apud Bessa and Funchal, 2012). Finally, the authors analyzed the relationship with regards to the value of the shares and did not find any evidence indicating that these facts are important enough to be considered by the investor during the allocation process; they have no economic relevance to the performance of funds (Bessa \& Funchal, 2012).

Scolese et al. (2015), compared the behavior of a real estate investment fund with other funds, such as fixed-income funds. The asset class factor model, which assesses the degree of exposure of investment fund portfolios with respect to other asset classes, was used to apply multiple regression, estimating the allocation of funds in different assets and measuring the risk and style of the fund (Sharpe apud Scolese et al., 2015).

When compared to the REIT (Real Estate Investment Trust) model, they found that its relationship with assets has changed over time, with a cyclical return intensity. Even then, they claim that there is a positive correlation between REITs and stocks, improving the risk-return ratio, and showing that investors can obtain benefits through diversification (Clayton and Mackinnon apud Scolese et al., 2015).

Maestri and Malaquias (2017) proved that economic factors that determine the degree of investment, such as high rates of inflation, interest rates, exchange rates, and international crises, had negative effects. This contradicts the argument that the financial market is affected by both political and economic issues. Their research used the multiple panel regression model, taking the Ibovespa benchmark, the dollar, and the SELIC (Sistema Especial de Liquidação e Custodia-Special System for Settlement and Custody) as independent variables that were exposed to market factors. Variable funds delivered higher returns when compared to fixed income, but in relation to risk-return, these were weakened by great volatility in the stock market (Trindade and Malaquias apud Maestri \& Malaquias, 2017).

Ceretta and Costa (2001) studied the performance of funds using data envelopment analysis, emphasizing the fact that analyses that use risk or return maximization models, simple return/risk ratios, and regressions with market indices are acceptable models in assessments that only consider information about risk and return. Nevertheless, the efficiency of such models is reduced, assuming that investors consider a larger set of information. For this reason, they took management costs into consideration in their analysis. Additionally, it was not necessary to use a representative market index with this methodology. Between funds considered inefficient and efficient, the former seeks dominance in short-term results and it is assumed that extreme attributes are not responsible for determining the best or worst performance, precisely because they are associated with other attributes and weightings (desirable or undesirable). Finally, the study lists reasons not only where to invest, but to also why not to invest in other funds (Ceretta \& Costa, 2001). 
Borges and Martelanc (2015) examined whether fund performance is due to luck or the active efforts of managers. They used the Fama and French (1993) and Carhart method, comparing simulated funds using random draws in which alpha was equal to zero. The proportion of real funds with abnormal returns was higher than that of simulated funds, converging on the idea that managers have the ability to deliver superior returns to investors, even after costs and expenses. With respect to the net equity size, larger funds yielded even more positive results when compared to the total sample, reinforcing the ability of managers. However, for small funds, no evidence regarding manager abilities was found (Borges \& Martelanc, 2015). Interestingly, Fama and French (1993) did not identify manager abilities; however, the advantage of the minority of managers who had some ability was canceled out by the fund expenses. This difference between the results can be due to the fact that the Brazilian market is less efficient, among other things.

By means of the scoring model (binary logistic regression) with positive and significant Jensen's alpha, analysis of past performance is highlighted as fundamental in selecting the best fund, contrasting with other applications (Júnior et al., 2017). As per the Sharpe index (SI), as the main factor for discriminating between fund and other portfolios, historical performance is the variable with the highest coefficient. As a complement, Júnior et al. (2017) revealed a certain behavior of the most successful managers in terms of positive return, indicating their concerns with regards to limiting the volatility linked to their risk exposures.

Milan and Júnior (2015) analyzed the determinants of portfolio turnover rates of investment funds with active management. Brazilian funds were evaluated for the period of 2007 to 2011 and it was concluded that the characteristics of each fund directly influence turnover rates. Large funds (measured by net equity) with a high initial investment positively affect the index (the higher the capital, the better the use of market opportunities). Furthermore, the greater the amount of time dedicated to the fund by the managers, the greater the increase in the turnover trend. However, experience and turnover are inversely correlated, as one rises, the other tends to decrease due to more passive management. A strategy profile and, consequently, turnover is also suggested: business majors tend to have greater turnover, while engineers and economists tend to turn less (Milan \& Júnior, 2015).

In the behavioral finance field, the disposition effect (the tendency to sell gainers faster than losers) directly influences the behavior of the investor/manager and the pricing of assets in the market (Tizziani et al., 2010). The hypothesis that the proportion of realized gains would be greater than that of losses in the market was tested using the Odean method (1998) (Odean apud Tizziani et al., 2010). The method consists of monthly analyses of the portfolio to identify how often gains and losses are sold when compared to their respective opportunities to be realized (Tizziani et al., 2010). The test concluded that sell-offs occur much 
faster with losers than with gainers (showing risk aversion), which is exactly the opposite of the disposition effect (Tizziani et al., 2010).

Similarly, Lucchesi (2010) examined the same effect through two competing behavioral motivations: prospect theory and the mean reversion bias. According to prospect theory, the choices of an individual are described according to the utilities of different results, which means that the rational individual will choose the prospect with the greater expected utility (S-shaped utility function) representing risk aversion and propensity over gains and losses, respectively. In mean reversion bias, a consistent sequence in performance in the past prompts distributors to classify a certain investment and start having biased expectations about future performance, establishing very high/low prices, generating a future return reversal, that is, an effect on reaction/overreaction. Of all the analyzed funds, it was confirmed that, based on the average purchase price used to determine a loss or gain, managers sold more gainers than losers (demonstrating the disposition effect). When analyzing the monetary volume, despite the fact that there were a greater number of transactions with gainers, the volume is proportionally smaller (not demonstrating the disposition effect, backing the study by Tizziani et al. (2010)). With regards to the performance of fund managers, approximately $78 \%$ showed signs of the disposition effect (referring to the number of transactions); by monetary volume, $57 \%$ of managers did not show signs of the effect, emphasizing the opposite result (Lucchesi, 2010).

Due to the wide range of studies on the subject and different results, the motivation that would lead investors and managers to behave rationally or emotionally during a certain period is controversial. This suggests a multitude of alternative series for future research, for example, the proportion of monetary transactions carried out by individual investors (Lucchesi, 2010).

When it comes to superiority in terms of performance, Casaccia et al. (2011) also examined the active performance of managers (selectivity and market timing) in relation to a benchmark. Using a quantitative approach (resources, techniques, and statistical models), they listed a sample of funds. Using Sharpe's model, they found that $49 \%$ of the funds outperformed benchmarking; however, after performing the Jarque-Bera normality test, the results showed that $53 \%$ of the funds rejected the null hypothesis of normality, indicating that the results from the SI model may not have significance (the model has a premise of normally distributed returns) (Casaccia et al., 2011).

On the other hand, when using the Treynor index (TI), they found that more than half of the sample yielded results that were superior to those from the benchmark, surpassing the SI model. It should be noted that the models differ in their approach to risks (total and systemic, respectively), thereby changing the classification of funds. With respect to market timing and selectivity abilities, none of the models used, including Jensen's alpha, Treynor-Mazuy (TM), and Henriksson and Merton (HM), yielded satisfactory results (Henriksson and Treynor apud Cassicia et al., 2011). The SI and TI confirmed the superiority of 
about half of the funds with respect to the benchmark, whereas TM and HM did not find this superiority, but reaffirmed that no evidence was found of timing by the managers (Casaccia et al., 2011).

When choosing to invest in a fund, the management fee charged by the institution that handles each fund (remuneration to fund managers due to the provision of their services) is one of the main items to be observed. Through the SI method, it was observed that there was no correlation between SI and the management fee variable (considering a significance level of 5\%). Interestingly, the management fee variable had a negative effect on the SI; the higher the rate, the lower the performance (Dalmácio et al., 2007). The linear correlation coefficient and the product-moment correlation coefficient were used for the analysis and a dispersion diagram was created. This result contradicts Rochman and Ribeiro (2010), who argued that the management fee is a variable that has negative effects on the SI (Dalmácio et al., 2007).

This may indicate the occurrence of information asymmetries in the industry, which means that people who do not have knowledge of the industry as a whole invest in funds with high management fees and low profitability, while more experienced investors look for funds with lower fees and higher profitability (Rochman \& Ribeiro, 2010). Given the current situation, where fund managers seek options to include environmental and social aspects in the formulation of investment portfolios, it is essential to incorporate concepts such as socially responsible investing (SRI).

Regarding evidence of impacts on financial performance and the risk-return ratio with respect to the corresponding benchmarks, the existence, or lack thereof, of variance differences in relation to the benchmarks was calculated using a one-tailed F-test. In terms of cumulative excess returns, the two-tailed T-test method was used, considering a significance level of $5 \%$ for both tests. Finally, the SI was also used to obtain the relative risk of international indices (dividing the portfolio risk premium by its standard deviation) (Campos \& Leme, 2009).

It was concluded that, with respect to international indices, the hypotheses regarding conditions of means and variances were not rejected, thereby implying that there are no differences in the financial performance of different sustainability indices. In brief, there was no positive or negative impact resulting from the inclusion of social and environmental criteria in the construction of portfolios (Campos \& Leme, 2009). These studies analyzed a wide range of time periods, discussing the particularities and characteristics that exist in the investment fund management compositions, the variables of which are presented in Table 1.

Given the studies presented herein, the following section outlines the research methodology, aiming at testing the main research hypothesis:

Main hypothesis: The allocation, management, and construction of portfolios are important to explain the performance of fixed-income funds in Brazil from 2011 to 2018. 
Table 1. Variables used in previous and present studies.

\begin{tabular}{|c|c|c|c|}
\hline Variable & Period & Objective & Base Study \\
\hline $\begin{array}{l}\text { SELIC, Ibovespa, } \\
\text { and the Dollar }\end{array}$ & 2009-2015 & $\begin{array}{l}\text { Risk-free rate and } \\
\text { benchmarks respectively, } \\
\text { used as comparison } \\
\text { measures for } \\
\text { excess returns }\end{array}$ & $\begin{array}{l}\text { Maestri and Malaquias } \\
\text { (2018) }\end{array}$ \\
\hline $\begin{array}{c}\text { Size, Market, Moment, } \\
\text { Resource, Cost/Rate, Flow, } \\
\text { Age, Quota Value, and Risk }\end{array}$ & 2001-2014 & $\begin{array}{l}\text { Analyze their behavior } \\
\text { with respect to the } \\
\text { fund performance }\end{array}$ & $\begin{array}{l}\text { Fonseca et al. (2018), } \\
\text { Bessa and Funchal } \\
\text { (2012), Iquiapaza } \\
\text { (2009), Ceretta and } \\
\text { Costa (2001), Dalmácio } \\
\text { et al. (2007), Rochman } \\
\text { and Ribeiro (2010) }\end{array}$ \\
\hline $\begin{array}{l}\text { Inflation, Interests, } \\
\text { Exchange Rate, } \\
\text { and Foreign Politics }\end{array}$ & 2001-2014 & $\begin{array}{l}\text { Analyze their behavior } \\
\text { with respect to the } \\
\text { fund performance }\end{array}$ & $\begin{array}{l}\text { Maestri and Malaquias } \\
\text { (2018) }\end{array}$ \\
\hline $\begin{array}{l}\text { Management, Turnover, } \\
\text { Initial Investment, } \\
\text { Education Level }\end{array}$ & $2007-2011$ & $\begin{array}{l}\text { Analyze their behavior } \\
\text { with respect to the } \\
\text { fund performance }\end{array}$ & $\begin{array}{l}\text { Milan and Júnior } \\
\text { (2015) }\end{array}$ \\
\hline $\begin{array}{l}\text { Environmental } \\
\text { and Social Aspect }\end{array}$ & 2005 & $\begin{array}{l}\text { Analyze their behavior } \\
\text { with respect to the } \\
\text { fund performance }\end{array}$ & $\begin{array}{l}\text { Campos and Lemes } \\
\text { (2009) }\end{array}$ \\
\hline $\begin{array}{l}\text { Management, Composition, } \\
\text { and Distribution Aspects } \\
\text { of the Portfolio: Portfolio } \\
\text { Composition, Manager } \\
\text { Experience, Number of } \\
\text { Funds Managed, Management } \\
\text { Fee, and Performance }\end{array}$ & & $\begin{array}{l}\text { Analyze their behavior } \\
\text { with respect to the } \\
\text { fund performance }\end{array}$ & Present study \\
\hline
\end{tabular}

Source: Developed by the author.

\section{Methodology}

The database was built using the CVM and Economica websites, as well as the institutional websites of each manager, concerning Brazilian fixed-income investment funds from January 2011 to December 2018, taking the recent work of Maestri and Malaquias (2018) as reference.

Data, including performance (SI and Sortino ratio), portfolio composition, net equity, management and performance fees, and a number of funds managed, were extracted from the platform. The starting date of the managers was obtained via the CVM and the institutional website of the managers.

This study conducted a descriptive analysis of active and passive funds, as well as of their relationship with CDI (Certificado de Depósito Interbancário, Interbank Deposit Certificate) returns, considered as the benchmark. The correlation matrix of the variables and a panel data analysis were evaluated.

SI and Sortino ratios were tested to assess fund performance. Regarding the "performance" variable (Índice Sharpe ${ }_{i t}$ ), monthly returns for each year of anal- 
ysis were selected with the purpose of estimating the SI for each fund in its respective year. The Sortino ratio was used to deal with the issue of robust results. The SI is one of the most popular performance indicators; it assesses the fund excess return and weights it based on its volatility (Varga, 2001). Even though the value for the Sortino ratio is inferred from the same premise as that for Sharpe, its denominator only takes the standard deviation of adjusted returns into account for its equation. In brief, the return dispersion is below the minimum acceptable return (Fonseca et al., 2007). Net returns and the SELIC, as the risk-free rate, were used to calculate the values.

The following variables were used to evaluate the management, composition, and distribution aspects of the portfolio: portfolio composition, manager experience, number of funds managed, management fee, and performance.

"Portfolio composition" variable (Comp. Cart $_{i t}$ ): Investments were clustered based on their respective degrees of similarity, given that they represented different types of assets with different specificities. This was accomplished through the segmentation between three portfolio groups: variable income, fixed-income, or neither (see the appendix for classification). The goal was to stratify assets according to their greater and/or lesser risk exposure. As with the "performance" variable, monthly returns were selected for each year of analysis, integrating annual calculations.

"Manager experience" variable (Exp.Gestor ${ }_{\mathrm{it}}$ ): to nominally measure the number of years of experience in the financial market given the difficulty of accessing this information publicly. The difference between the base date of January 1,2019 and the manager's starting date was then calculated.

"Number of funds managed" variable (Qde.F.Adm ${ }_{i t}$ ): The number of funds managed by each manager during the period was counted, aiming at measuring whether a larger amount positively affects the performance of funds. Bryant (2012) claimed that due to the effect on expenses, volume and, mainly, distribution styles, there is an increase in performance for distribution structures through which multiple funds are managed than for those with a single fund. On the other hand, Prather apud Maestri and Malaquias (2018) reported that as the manager tries to handle more funds, there is a loss of focus and effectiveness in delivering results.

"Management fee" (Administration Fee ${ }_{i t}$ ): Variable refers to a fee used to meet the expectations of investors and the manager, paying for the work of managers, fund costs, and commission transfers, established through a percentage of the fund equity (Ackermann et al. apud Maestri and Malaquias, 2018). The "performance fee" variable reflects the ability of the manager to generate returns above benchmarking and is collected depending on the characteristics that are present or absent in each fund. Therefore, managers who perform better and yield higher returns tend to charge higher rates (Maestri and Malaquias, 2018). The relationship between the management and performance fees is with respect to the performance diverge. According to Rochman and Ribeiro (2010), 
the management fee and the performance of the funds are negatively correlated. Meanwhile, there is a positive relationship between the performance fee and returns (Júnior apud Maestri and Malaquias, 2018). As such, the maximum management fee was analyzed and, with respect to performance, defined in the model as a dummy variable, assuming a value of 1 for funds that have it and 0 for the others.

"Performance" (Administration $\mathrm{Fee}_{i t}$ ): The "fund size" variable was calculated annually with monthly samples from each year and measured through the net equity of its respective fund. This relationship behaved negatively in developed countries given that the growth of funds without the due increase in the number of assets reduces the optimal distribution of resources in the portfolios (Grupta and Jithendranathan apud Maestri and Malaquias, 2018). In contrast, the relationship between the fund size in Brazil and its performance was found to be positive (Júnior apud Maestri and Malaquias, 2018).

The variables previously presented allowed the hypotheses regarding portfolio composition, manager characteristics, and the performance of Brazilian fixedincome funds to be evaluated. The following equations were used in the measurement models.

Indice de Sharpe ${ }_{i t}$

$=\beta_{0}+\beta_{1}$ Fixed income Composition $_{i t}$

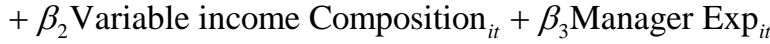

$+\beta_{4}$ Number of Managed Funds ${ }_{i t}+\beta_{5}$ Administration Fee $_{i t}$

$+\beta_{6}$ Performance Fee $+\beta_{7}$ Size $_{i t}+\varepsilon_{i t}$

Indice de Sortino ${ }_{i t}$

$=\beta_{0}+\beta_{1}$ Fixed income Composition ${ }_{i t}$

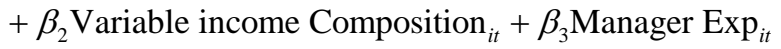

$+\beta_{4}$ Number of Managed Funds $_{i t}+\beta_{5}$ Administration Fee $_{i t}$

$+\beta_{6}$ Performance Fee $+\beta_{7}$ Size $_{i t}+\varepsilon_{i t}$

Robust regressions were used using the MM estimator. This procedure was adopted as the standardized residues resulting from the regression model did not present a normal distribution through the Shapiro-Wilk test (at a significance level of 5\%). Regarding the multicollinearity problems, the variance inflation factor (VIF) was used and, paying special attention to the treatment of extreme outliers, the variables underwent a $1 \%$ winsorization procedure, removing the bias from the model coefficients (Verardi and Croux apud Maestri and Malaquias, 2018).

Finally, the analysis of the hypotheses was performed within confidence intervals as they can expand the statistical results to economic results. In this sense, statistical techniques, such as variance, volatility, risk, and standard deviation, were used to compare yields and performance. The calculation of the above technical procedure is characterized as ex-post, which means that the obtained data are from returns already recorded in the literature. The collected data were 
analyzed by Stata and, after obtaining the results, were displayed in the form of graphs and tables.

\section{Results}

Table 2 presents the descriptive statistics used in this study. In the period from January 2011 to December 2018, the fixed-income fund sample was composed of 1039 funds and 6197 annual observations, with a mean SI of -4.44 , which means that, on average, the funds showed monthly returns below the risk-free rate, yielding negative returns to shareholders in most cases.

Table 3 (2667 annual observations) reports the results from the hypothesis tests regarding the interference of portfolio composition and variables related to managers in the performance of Brazilian fixed-income funds. Table 3 shows that the average percentage allocated to assets classified as fixed-income showed

Table 2. Descriptive statistics of the variables for testing the hypotheses (January 2011 to December 2018).

\begin{tabular}{cccccc}
\hline Variables & Observations & Mean & SD & Minimum & Maximum \\
\hline Sharpe's Index & 6197 & -4.445 & 8.561 & -47.4 & 2.8 \\
Sortino Ratio & 6236 & -0.703 & 3.251 & -3.80 & 14.5 \\
Fixed Income Composition & 2985 & 16.263 & 6.230 & 0.088 & 25.096 \\
Variable Income Composition & 6774 & 4.0311 & 2.346 & 0 & 6.161 \\
Manager Exp. & 8296 & 63.575 & 43.457 & 1 & 175 \\
Number of Managed Funds & 8296 & 98.458 & 73.840 & 1 & 202 \\
Administration Fee & 8296 & 0.828 & 0.377 & 0 & 1 \\
Performance Fee & 8296 & 0.061 & 0.240 & 0 & 1 \\
Size (Net Equity) & 6756 & $1,335,796$ & $3,108,433$ & 1479.70 & 19,800 \\
\hline
\end{tabular}

Source: Compiled by the author.

Table 3. Estimation of the interference of factors in the risk-adjusted returns of Brazilian fixed-income funds.

\begin{tabular}{|c|c|c|c|}
\hline Sharpe & Coefficient & Robust Standard Error & P-Value \\
\hline Fixed-Income Comp. & $0.040^{* * *}$ & 0.012 & 0.000 \\
\hline Variable Income Comp. & 0.004 & 0.058 & 0.940 \\
\hline Manager Exp. & $-0.002^{* * *}$ & 0.002 & 0.000 \\
\hline Numb. Managed Funds & $0.011^{\star * *}$ & 0.003 & 0.000 \\
\hline Administration Fee & -1.144 & 0.207 & 0.385 \\
\hline Performance Fee & $1.205^{\star * *}$ & 0.400 & 0.000 \\
\hline Size (Net Equity) & $0.001^{\star * *}$ & 0.001 & 0.003 \\
\hline Constant & $-2.789^{\star * \star}$ & 0.718 & 0.000 \\
\hline
\end{tabular}

Source: Compiled by the author. 
a positive relationship with the risk-adjusted return of the sample funds. A possible explanation for this positive relationship is that, first and in accordance with Instruction 555 from the CVM, the definition and regulations of fixedincome investment funds require a minimum of $80 \%$ of the net equity be allocated to assets of this type. As such, a positive ratio of assets in this category was to be expected given that it coincides with the main objective of the fund.

In addition, its main risk factor is the variation of interest rates and the price index, leading to a second explanation for the result, that is, an increase in the Brazilian interest rate (SELIC) was observed over the period, such that a favorable economic environment for fixed-income investments was created. For example, as per data released by the Central Bank of Brazil, the SELIC annual rate was $8.90 \%$ in September 2013, 10.90\% in September 2014, and 14.15\% in September 2015.

Nonetheless, CVM Instructions state that fixed-income funds can invest in other securities and strategies with a higher degree of risk, such as derivatives, to increase and/or protect their performance in more turbulent times. The results displayed a possible positive relationship between allocation to variable-income funds and the performance of these funds where it would be possible to use hedge strategies to reduce volatilities (Maestri \& Malaquias, 2018) and, consequently, losses, thereby being able to deliver better risk-adjusted returns. Despite this relationship, it was not statistically significant. It is worth noting that, after the performance fee, the fixed-income portion of the portfolio is the variable that most aids in explaining the risk-adjusted return of the fixed-income funds in the sample.

As such which proposed that there is no relationship between portfolio composition and the performance of fixed-income funds in Brazil, was rejected.

With the purpose of expanding and strengthening the study, more elements were added to the analysis of the results. The Sortino ratio was used instead of the SI, as the second index analyzes only the volatility of undesired returns.

According to Table 4, which used a different indicator for risk-adjusted returns (Sortino ratio), the results point to the same conclusion. A positive relationship between the sample funds and the percentage allocated to fixed-income assets with similar degrees of significance was noted.

The second variable analyzed was the manager experience, which represents time as a manager since their starting date. Contrary to expectation, results indicate that a less experienced manager is able to deliver higher fund returns when compared to managers that have already accumulated more specific knowledge, experience, and, theoretically, competence. A possible explanation for this is that managers that are new to the market may have more incentives in terms of seeking truly superior performances with the goal of establishing themselves in the industry than those already established. This may be the result of having a long career ahead, for example, which could make them more likely to take risks (Maestri \& Malaquias, 2018). 
Table 4. Estimation of the interference of factors in the risk-adjusted returns of Brazilian fixed-income funds: Sortino ratio.

\begin{tabular}{cccc}
\hline Sortino & Coefficient & Robust Standard Error & P-Value \\
\hline Fixed Income Comp. & $0.077^{* * *}$ & 0.024 & 0.001 \\
Variable Income Comp. & -0.041 & 0.088 & 0.641 \\
Manager Exp. & -0.001 & 0.002 & 0.440 \\
Numb. Managed Funds & $0.004^{* * *}$ & 0.001 & 0.009 \\
Administration Fee & $-1.093^{* * *}$ & 0.241 & 0.000 \\
Performance Fee & $0.913^{* * *}$ & 0.337 & 0.007 \\
Size (Net Equity) & $0.001^{* *}$ & 0.001 & 0.000 \\
Constant & -0.812 & 0.667 & 0.223 \\
\hline
\end{tabular}

Source: Compiled by the author.

The number of funds managed was the third variable to be analyzed. Contrary to expectation, the result showed a positive relationship in both indices, demonstrating that managers who manage a higher number of funds are able to deliver better risk-adjusted returns than managers who focus on fewer funds. This result can be explained by the fact that a multiple fund management structure interferes with administration expenses, the volume of portfolio operations and, consequently, changes in style and strategy, resulting in economies of scale and optimization of discretionary allocation costs (Bryant apud Maestri \& Malaquias, 2018).

With respect to independent variables, the management fee displayed a negative relationship with regards to fund risk-adjusted returns. As previously expected and proven by Rochman and Ribeiro (2010), the inconsistency between the deduction of the management fee with respect to performance means that the benefits of active management do not directly stay with the shareholders (Shukla apud Maestri \& Malaquias, 2018).

However, the performance fee displayed a positive relationship with the fund risk-adjusted returns, which is contrary to expectation. A possible explanation for this relationship is the fact that this fee promotes good manager performance in exceeding their benchmark, thereby generating higher profitability for shareholders and, simultaneously, manager remuneration.

Finally, the fund size (net equity) was the last variable to be analyzed. There was a notable positive relationship with the risk-adjusted return, a fact that is in line with expectations. This is probably due to a greater availability of resources, which resulted in a more efficient allocation of assets, generating diversification that may affect the performance of the funds.

Based on a different method of analyzing the risk-adjusted returns, other than using the statistical significance of the coefficients of the variables, confidence interval (CI) analysis allows the statistical results to be expanded to economic results (Ledoi and Wolf apud Maestri \& Malaquias, 2018). 
Consequently, considering the CIs of the variables observed displayed in Table 4 , the variable that most contributes to the study of the risk-adjusted return is the performance fee with a confidence interval between 0.421 and 1.989. This means that, according to the proposed model and based on the data from this work, the performance variable contributed to a possible change in the returns of up to 1.205. It is important to emphasize that this value is higher than the average SI of the sample which, according to Table 3, is -4.445 .

In brief, and in accordance with Table 5, the current study found that effective active management is carried out by less experienced managers, who have a higher position in fixed-income assets, as well as by managers who manage multiple funds, along with funds that have greater net equity. All of these factors behaved positively in terms of generating better risk-adjusted returns.

\section{Final Considerations}

This study analyzed Brazilian fixed-income investment funds to identify whether certain characteristics related to their managers and consequent variables either positively or negatively affect their risk-adjusted returns. The results demonstrated that the variables that could best explain a possible change in performance were the performance fee and the proportion of fixed-income assets in the portfolio. Furthermore, these results can directly help investors and future shareholders.

The results suggest that managers with less experience will obtain (on average) better risk-adjusted returns when compared to those with more experience. This could be explained by the fact that, among many different reasons, managers with less experience have excess confidence and a greater appetite for risk as they are seeking to establish a future career in the market. Hence, when correlating good performance with career advancement, their management style is more exposed to risks in search of profitability (Chevalier and Ellison apud Maestri \& Malaquias, 2018).

The study database was composed of a sample of 1,039 Brazilian fixed-income funds, each of which had at least 11 months of published information represented by the average monthly percentage, enabling us to calculate variables annually. Based on this, the results revealed that a relatively inexperienced management, combined with a portfolio composition focused on fixed-income assets, low

Table 5. Analyzed variables and expected and actual relationships.

\begin{tabular}{ccc}
\hline Variable & Expected Relationship & Actual Relationship \\
\hline Fixed-Income Composition & + & + \\
Manager Exp. & - & - \\
Number of Managed Funds & - & + \\
Administration Fee & - & - \\
Performance Fee & + & + \\
Size (Net Equity) & + & + \\
\hline
\end{tabular}

Source: Compiled by the author. 
management fees, larger size (net equity) and, mainly, higher performance fees, delivered better risk-adjusted returns over the period. It is important to note that two analysis indexes (Sharpe and Sortino) were used to check the robustness of the results, including the analysis of the $95 \%$ confidence intervals.

The main contribution of the research is the evaluation of the impact of the variables presented in the fund performance. The results are important for the Brazilian market since the resources invested in the funds represent a significant portion of the total reecursos applied in the local capital market. These findings select the agents for a better evaluation of the funds and, consequently, a greater efficiency in the allocation of resources.

The data sample has the following limitations. First, due to the lack of information collected from the Economica database, proxies were created to measure the manager experience variable. The second refers to the subjective way in which different assets that were part of the portfolio were classified into fixedincome, variable income, or neither. According to the CVM, fixed-income funds can allocate up to $20 \%$ of their equity to securities or strategies of other types, such that the multiplicity of assets present in the database are dispersed into 35 types.

The classification of these assets followed, a priori, the instructions of the CVM and the ANBIMA regarding financial characteristics and behaviors. However, due to the lack of a framework in the instructions provided by these regulatory bodies, these may have been classified subjectively at certain points.

The third limitation refers to obtaining and organizing the information for the sample through a databank; when no information was available in this databank, the details were directly taken from the institutional website. Despite the full usability and representativeness of these data, if they have any limitations and/or mistakes in their availability or in the relative organization of their database, the final considerations of this work will be directly subject to the same problem.

Finally, with the goal of encouraging future research and contributing to the progress of academia, a more detailed study on the behavior of Brazilian fixedincome funds from 2018, in which the results are compared with those from the current study, is suggested. This is because, according to the Central Bank of Brazil, the country is currently witnessing a historical minimum rate of SELIC. As such, it would be interesting to compare the portfolio composition and whether, as the main risk factor, there would be changes to the risk-adjusted return.

Similarly, in the event that there is a decrease in the performance fee charged by managers, it would be interesting to analyze whether that decrease would positively or negatively impact the returns delivered to shareholders.

\section{Conflicts of Interest}

The authors declare no conflicts of interest regarding the publication of this paper. 


\section{References}

Associação Brasileira das Entidades dos Mercados Financeiros e de Capitais (2018). Consolidado Histórico de Fundos de Investimento. São Paulo.

Bessa, L. M., \& Funchal, B. (2012). Determinantes em performance dos fundos de investimentos em açôes no Brasil. http://www.fucape.br/ public/producao cientifica/2/LUCAS\%20MARIN\%20BESSA.p $\underline{\text { df }}$

Borges, E. C., \& Martelanc, R. (2015). Sorte ou habilidade: Uma avaliação dos fundos de investimentos no Brasil. Revista de Administração, 50, 196-207. https://doi.org/10.5700/rausp1194

Campos, F. M., \& Lemme, C. F. (2009). Investimento socialmente responsável no mercado de capitais: Análise do desempenho de índices internacionais e fundos de ações brasileiros que consideram questões ambientais e sociais. Revista Eletrônica de Administração, 13, 287-306.

Casaccia, E. C., Galli, O. C., Macêdo, G. R., \& Leitão, C. (2011). Análise do desempenho de fundos de investimentos: Um estudo em ações brasileiras no período de janeiro de 2004 a agosto de 2009. São Bernardo do Campo.

https://www.metodista.br/revistas/revistas-ims/index.php/OC/article/viewFile/2711/pd $\underline{\mathrm{f} 22}$

https://doi.org/10.15603/1982-8756/roc.v7n13p1-30

Ceretta, P. S., \& Costa, N. C. A. (2001). Avaliação e seleção de fundos de investimentos: Um enfoque sobre múltiplos atributos. Revista de Administração Contemporânea, 5, 7-22. https://doi.org/10.1590/S1415-65552001000100002

Dalmácio, F. Z., Nossa, V., \& Filho, H. Z. (2007). Avaliação da relação entre a performance e a taxa de administração dos fundos de ações ativos brasileiros. Revista de Educação e Pesquisa em Contabilidade, 1, 1-20. https://doi.org/10.17524/repec.v1i3.13

Fama, E. F., \& French, K. R. (1993). Common Risk Factors in the Returns on Stocks And bonds. Journal of Financial Economics, 33, 3-56. https://doi.org/10.1016/0304-405X(93)90023-5

Fonseca, N. F., Bressan, A. A., Iquiapaza, R. A. \& Guerra, J. P. (2007). Análise do desempenho recente de fundos de investimento no Brasil. Contabilidade Vista \& Revista, 18 , 95-116.

Fonseca, S. E., Fernandes, A. R., Cunha, C. L., \& Iquiapaza, R. A. (2018). Fundo de investimento: Performance aplicando modelo Carhart e análise envoltória de dados. Revista de Administração Contemporânea, 22, 355-379.

https://doi.org/10.1590/1982-7849rac2018170174

Iquiapaza, R. (2009). Performance, captação e foco das famílias de fundos de investimentos. Dissertação (Doutorado em Administração), Minas Gerais: Universidade Federal de Minas Gerais.

Júnior, J. A. M., Campani, C. H., \& Leal, R. P. C. (2017). A escolha de fundos de ações e o investidor individual. Revista de Administração Contemporânea, 21, 41-62. https://doi.org/10.1590/1982-7849rac2017160037

Lucchesi, E. P. (2010). O efeito disposição e suas motivações comportamentais: Um estudo com base na atuação de gestores de fundos de investimento em ações. Dissertação (Doutorado em Administração), São Paulo: Universidade de São Paulo.

Maestri, C. O. M. N., \& Malaquias, R. F. (2017). Exposição a fatores de mercado de fundos de investimentos no Brasil. Revista de Contabilidade \& Finanças, 28, 61-76.

https://doi.org/10.1590/1808-057x201702940 
Maestri, C. O. M. N., \& Malaquias, R. F. (2018). Aspectos do Gestor, Alocação de carteiras e desempenho de fundos no Brasil. Revista de Contabilidade \& Finanças, 29, 82-96. https://doi.org/10.1590/1808-057x201804590

Milan, P. L. A. B., \& Júnior, W. E. (2015). Determinantes da Rotatividade das Carteiras dos Fundos em Ações. Brazilian Business Review, 12, 1-16.

https://doi.org/10.15728/bbr.2015.12.5.1

Rochman, R. R., \& Ribeiro, M. P. (2010). A relação entre a estrutura, conduta e desempenho da indústria de fundos de investimento: um estudo de painel. São Paulo: Encontro Brasileiro de Finanças. https://www.sbfin.org.br

Scolese, D., Bergmann, D. R., Da Silva, F. L., \& Savoia, J. R. F. (2015). Análise de estilos de fundos imobiliários no Brasil. Revista de Contabilidade e Organizações, 9, 24-35. https://doi.org/10.11606/rco.v9i23.83452

Tizziani, E., Ness Jr., W. L., Klotzle, M., \&Motta, L. F. (2010). O Efeito Disposição na Indústria Brasileira de Fundos de Investimentos em Ações. Revista Brasileira de Finanças, 8, 383-416. https://doi.org/10.12660/rbfin.v8n4.2010.1651

Varga, G. (2001). Índice de Sharpe e Outros Indicadores de Performance Aplicados a Fundos de Ações Brasileiros. Revista de Administração Contemporânea, 5, 215-245. https://doi.org/10.1590/S1415-65552001000300011 